\title{
The role of Malcolm Clarke (1930-2013) in the Azores as a scientist and educationist
}

\author{
J.N. GOMES-PEREIRA ${ }^{1,2}$, R. PRIETO ${ }^{1}$, V. NEVES ${ }^{1}$, J. XAVIER ${ }^{3}$, C. PHAM ${ }^{1}$, J. GONÇALVES ${ }^{1}$, F. PORTEIRO ${ }^{1}$, \\ R. SANTOS $^{1}$ AND H. MARTINS ${ }^{1}$ \\ ${ }^{1}$ University of the Azores, LARSyS Associated Laboratory, IMAR and Department of Oceanography and Fisheries, ${ }^{2}$ Portuguese Task \\ Group for the Extension of the Continental Shelf (EMEPC), Rua Costa Pinto 165, 2770-047 Paço de Arcos, Portugal, ${ }^{3}$ Institute of \\ Marine Research (IMAR-CMA), Department of Zoology, University of Coimbra, 3004-517 Coimbra, Portugal and British Antarctic \\ Survey, Natural Environment Research Council, High Cross, Madingley Road, CB3 oET Cambridge, USA
}

\begin{abstract}
Malcolm Roy Clarke (1930-2013) was a British teuthologist who made an important contribution to marine science in the Azores archipelago (Portugal). Malcolm started doing research in the Azores from 1980 s onward, settling for residency in 2000 after retirement (in 1987). He kept publishing on Azorean cephalopods collaborating in $20 \%$ of the peer reviewed works focusing on two main areas: dietary studies; and the ecology of cephalopods on seamounts. Since his first visit in 1981, he was involved in the description of the dietary ecology of several cetaceans, seabirds, and large pelagic and deep-water fish. Using his own data, Malcolm revised the association of cephalopods with seamounts, updating and enlarging the different cephalopod groups according to species behaviour and ecology. Malcolm taught several students working in the Azores on cephalopods and beak identification, lecturing the Third International Workshop in Faial (2007). He empowered the recently established research community, by providing important contacts with foreign institutes and informal advice. He collaborated in the regional cetacean stranding network (RACA) and was an active member of the advisory board of the journal Arquipelago-Life and Marine Sciences. But the scientific role of Malcolm Clarke in the Azores went beyond his academic activities. In the last 10 years Malcolm and Dot Clarke dedicated themselves to building and running a museum on Pico Island, showing the biology of the sperm whale and its interaction with squid; a cultural and touristic legacy for future generations to enjoy.
\end{abstract}

Keywords: teuthologist, cephalopods, Azores, Malcolm R. Clarke, museum

Submitted 16 December 2013; accepted 14 May 2014; first published online 8 July 2014

Malcolm R. Clarke (1930-2013) had a long and illustrious career in the fields of cetology and teuthology (Rodhouse et al., 2014; Vidal et al., 2014). Having undertaken research in every continent, he chose Pico Island (Azores, Portugal) to work and live during the last phase of his career. Malcolm made his first visit to the Azores in 1981 while working at the Marine Biological Association of the United Kingdom (MBA). He started studying the diet of sperm whales (Physeter macrocephalus) using individuals landed at the São Roque whaling station on Pico Island. The work was undertaken until 1984 in close collaboration with the recently created Department of Oceanography and Fisheries from the University of the Azores (DOP/UAz, established in 1976). After retiring from MBA in 1987 he went on doing research and teaching about deep-diving cetaceans and their elusive cephalopod preys.

\section{CONTRIBUTION OF MALCOLM CLARKE TOSCIENCE IN THE AZORES}

After his first visits to the Azores between 1981 and 1984, in the early 1990 s Malcolm and his wife Dorothy (Dot) Clarke bought

Corresponding author:

J.N. Gomes-Pereira

Email: josenunopereira@uac.pt a house on Pico Island and moved there permanently in 2000. During his 'Azorean period' Malcolm continued doing research and became visiting scholar at the University of the Azores, Portugal (1990-2011). He had an important role in the research conducted by numerous colleagues in the region, either through formal or informal advice, directly participating in their work or by training and/or supervising them. These aspects are discussed in detail below.

It would be expected that the presence of a prolific researcher such as Malcolm Clarke would have a positive impact on the scientific output of an ultra-peripheral region such as the Azores. To test that premise we set to gauge Malcolm's contribution to the region in the field of teuthology, his chief line of research. We compiled a list of peer-reviewed publications from 1981 that reported cephalopod occurrences and analysed samples or re-analysed datasets from the Azores region. Such works were considered to provide new insights, improving knowledge or revising research topics including Azorean cephalopod fauna. Using internet databases and search engines (webofknowledge. com, google scholar, etc.), we examined each paper or abstract if only that available. This method can miss relevant publications. However, there is no reason to believe that this approach favours the presence of any author over others. Thus it was considered that it would give a fair sample of an individual's contribution to a research field for any given geographical area.

A total of 67 peer-reviewed publications on Azorean cephalopods were published from 1981 to 2012, where 


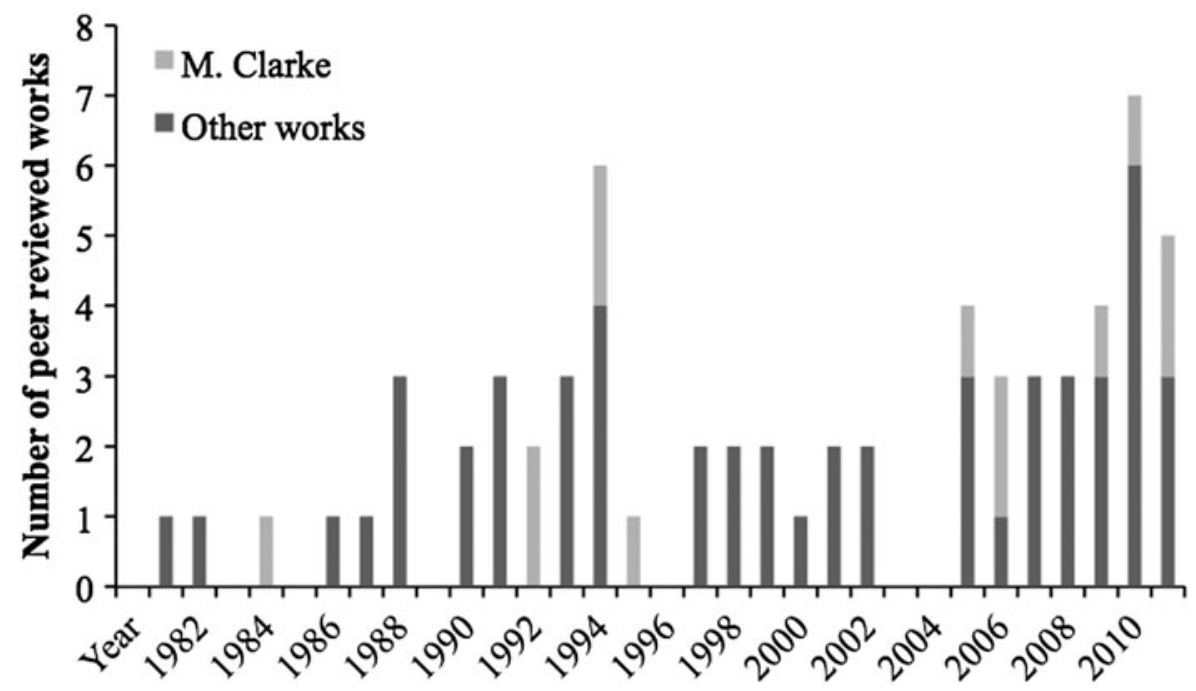

Fig. 1. Number of peer reviewed works regarding Azorean cephalopods published between 1981 and 2012; publications where Malcolm R. Clarke was leading or co-author are indicated in light grey.

Malcolm was involved in 14 papers, as leading (Clarke et al., 1993, 1995, 1996; Den Hartog \& Clarke, 1996; Clarke, 2006, 2007) or co-author (Martins et al., 1985; Brierley et al., 1993, 1995; Xavier et al., 2007; Pereira et al., 2010; Neves et al., 2011, 2012a, b). His contribution was also acknowledged in several other publications. While this may be considered a small number for today's scientific productivity, it is in good agreement with the productivity of the small teuthologist community in the Azores during that period, comprising $\sim 20 \%$ of the peer-reviewed published material (see publication criteria above; Figure 1). It should also be put in perspective that Malcolm came from a period well before web-based research, he was entering retirement, and he was also publishing on data collected elsewhere (e.g. Clarke \& Pascoe, 1997). Morever, it was during this period that he published some of his most important contributions (e.g. Clarke, 1986a, 1996). One example was the seminal editorial work in the Philosophical Transactions of the Royal Society on 'The Role of Cephalopods in the World's Oceans' (Clarke, 1996), from where we derived the name of this contribution.

Malcolm kept on publishing until his last years, as shown in Figure 1. Also a hiatus from the mid-1990s to the early 21st Century is demonstrated, which corresponds to the period of development and opening of the Museum on Whales and Squid (discussed below). The research topics are discussed in the following section. This rather simplistic bibliometric analysis attempts to quantify Malcolm's contribution to the study of cephalopods in the Azores. However, it fails to show his contribution to other fields and his role in providing the tools for other researchers to carry on their work, which we attempt to grasp in the sections below.

\section{Research}

Malcolm's research and contribution to the knowledge about the Azorean marine ecosystem focused on two main areas, dietary studies of selected predators and the ecology of cephalopods on seamounts.

\section{DIETARY STUDIES}

Malcolm was one of the first marine scientists to recognize the potential of beak identification not only to the study of cephalopods but also of their predators and of the functioning of entire ecosystems (Clarke, 1962a, b; Clarke \& Merrett, 1972).

In a talk given in Semana das Pescas ('Fisheries Week', an international meeting with fishermen, scientists and politicians focused on all aspects of fisheries that was held yearly in Faial Island from 1981 to 2004 (Clarke \& Martins, 1994)) in 1994, entitled 'Marine Azorean Foodwebs-The Known, the Unknown and the Unlikely' (Week of Fisheries, Clarke \& Martins, 1994), Malcolm explained his approach on how to better understand the Azorean marine ecosystem and predict how shifts in the community were caused by environmental or anthropogenic changes. This included identifying: (1) how species interrelate; (2) which species are critical to sustain the present balance; and (3) how the islands depend on the oceanic ecosystem. In his own words, it would 'take us a long way towards understanding the ecosystem, (...) providing data to the models', a picture only given by 'research nets after much more of the inter-relationships between species are known'.

In the 1980s, Malcolm initiated a series of dietary studies collaborating with several colleagues from the Azores. In the following years he further collaborated with some of his students on other dietary works. This included sorting and identifying thousands of squid beaks and fish otoliths from the stomachs of sperm whales (Physeter macrocephalus), pigmy sperm whales (Kogia breviceps), Sowerby beaked whales (Mesoplodon bidens), blue sharks (Prionace glauca), swordfish (Xiphias gladius), orange roughy (Hoplostethus atlanticus), Cory's shearwaters (Calonectris diomedea) and Barolo shearwaters (Puffinus baroly) (Martins et al., 1985; Clarke et al., $1993,1996)$. Some other studies in that line of work are still underway, including studies on the diet of other cetaceans and benthopelagic fish (J.G.P. and R.P.).

Dietary studies in the Azores continue to occur but only sporadically and at a much lower number than Malcolm hoped for, mainly caused by the lack of funds for such research. Besides the above mentioned works, and the works 
by T. Morato on several demersal fish (e.g. Morato et al., 2000, 2003), the diet of many of the most important commercial species in the Azores is still unknown (e.g. Wreck fish Polyprion americanus, Thunnus obesus, etc). Such lack of data remains a concern today (Guénnette \& Morato, 2001; Lemey, 2013), limiting the development of whole ecosystem models in support of ocean management.

\section{SEAMOUNT CEPHALOPOD ECOLOGY}

Interest in seamount research has greatly increased in the last two decades, after they were recognized as a major habitat in the high seas (Pitcher et al., 2007). Within an international effort to improve our understanding of seamount habitats, where the Azorean scientific community provided a crucial input (e.g. Pitcher et al., 2007), Malcolm revised the association of cephalopods with seamounts, by compiling his previous works on the vertical distribution of oceanic cephalopods in the eastern North Atlantic (Clarke, 2006), using data from nets (a great number with C.C. Lu), dietary studies and unpublished records. He provided an updated and enlarged version of the groups of oceanic cephalopods occurring near seamounts as proposed earlier by Nesis (1993), according to species behaviour and ecology (Clarke, 2007). These works are of relevance not only for regional marine research but also for the regional strategies related to marine governance and economy. With oceanic cephalopods being a key zoological group in seamount food webs, acting both as predators and prey, understanding their ecology in these ecosystems is of paramount importance to understand and manage seamounts. Obviously, that becomes even more relevant in seamount dominated ecosystems such as the Azorean plateau. As an example, such seamount cephalopod groups have been used to investigate if the cephalopod food source of deepwater schooling fish were autochthonous or allochthonous to seamounts that were inhabited by them (Pereira et al., 2010).

\section{OTHER WORKS}

Driven by his natural fascination about marine life, combined with an endless energy, Malcolm continued doing research until his last days. Other unpublished works include identification keys for the Azores. With a long career in teuthology, having published several systematic keys, procedure manuals and guides for the use of cephalopod beaks (e.g. Clarke, $1962 \mathrm{~b}, 1966,1986 \mathrm{a}, \mathrm{b})$ he compiled a poly-copied systematic key on cephalopods of the Azores, entitled 'Identification of Cephalopods and their Lower Beaks. Azores Region'. It includes a checklist with indication of depths of occurrence and habitat, and identification keys for the Cranchiidae of the north-west Atlantic as well as the Histioteuthidae and the Octopoda of the Azores. These keys have been a valuable reference for many of his students and colleagues working with specimens collected in the Azores, and are currently under revision to be published in the near future.

Malcolm was working on the description of new cephalopod species based on fossile statoliths by the time he left us. It was a work he was developing alone and the authors were not able to obtain further information.

\section{Teaching}

Malcolm further passed on his legacy by teaching several individual graduate and post-graduate students working in the Azores on cephalopods and beak identification. For example, between 1997 and 2000, Malcolm was a guest scientist of the project AMIR on Azorean seabird food webs, giving personal training to V. Neves at his home in Ancarva (UK).

Malcolm also lectured the 'Third International Course on Cephalopod Beak Identification' in Faial, Azores, in 2007 (Xavier et al., 2007), after Plymouth 1981 and Aberdeen 2000 (Hatfield \& Hochbergand, 2002). Organized by José Xavier (Institute of Marine Research of the University of Coimbra and British Antarctic Survey) and Maria Carvalho (Centre of IMAR at the University of the Azores), it aimed 'to increase knowledge about this technique and stimulate a new generation of beak experts' (Xavier et al., 2007; Figure $2 \mathrm{C}, \mathrm{D}$ ). Through this workshop Malcolm managed to pass on some of his knowledge in cephalopod beak identification and biomass estimation to several young researchers working in the Azores, Spain, France, Greece, United States and the UK (for a complete list of the participants refer to Xavier et al., (2007)).

\section{Other contributions}

Malcolm's collaboration with the Azorean marine researchers, particularly from the Department of Oceanography and Fisheries/UAz in Faial Island, was beneficial beyond his professional production and academic teaching. Arriving to the Azores in the early years of the DOP/UAz local research department, Malcolm contributed by introducing the local scientists to several foreign researchers and institutes, from which profitable collaborations emerged (e.g. Pat Hargreaves, IOS; Steve Hawkins, Isle of Man, Liverpool University, etc.). He also contributed by providing copies of bibliographical material and offered field experience to local scientists by inviting them onboard HRM 'Challenger' in 1983-1984. He integrated the advisory board of the DOP/ UAz Journal Arquipelago-Life and Marine Sciences 19902013, collaborated in the cetacean stranding network RACA, as well as in the identification of the occasional encounter of unusual oceanic cephalopods.

Other contributions include the provision of scientific advice to local researchers and ongoing research (such as on pelagic sampling). He was also occasionally invited onboard the IFAW 'Song of the Whale' research ship doing surveys on large cetaceans in the region (Figure 2).

\section{MALCOLM CLARKE, THE CDMMUNICATDR}

Malcolm was an excellent communicator: in informal conversation, in the course of scientific talks, or as a lecturer or in wildlife documentaries. He was often theatrical, and would grab the attention of his audience not only by using an accurate but accessible discourse even for the lay person, but also by resorting to props from actual specimens to back his statements.

He helped project the name of the Azores abroad not only through the publication of his scientific work and by presenting it at international fora, but also through his participation in high profile wildlife documentaries.

\section{Wildlife documentaries}

He participated in two National Geographic documentaries filmed in the Azores, associated with the search for a giant 


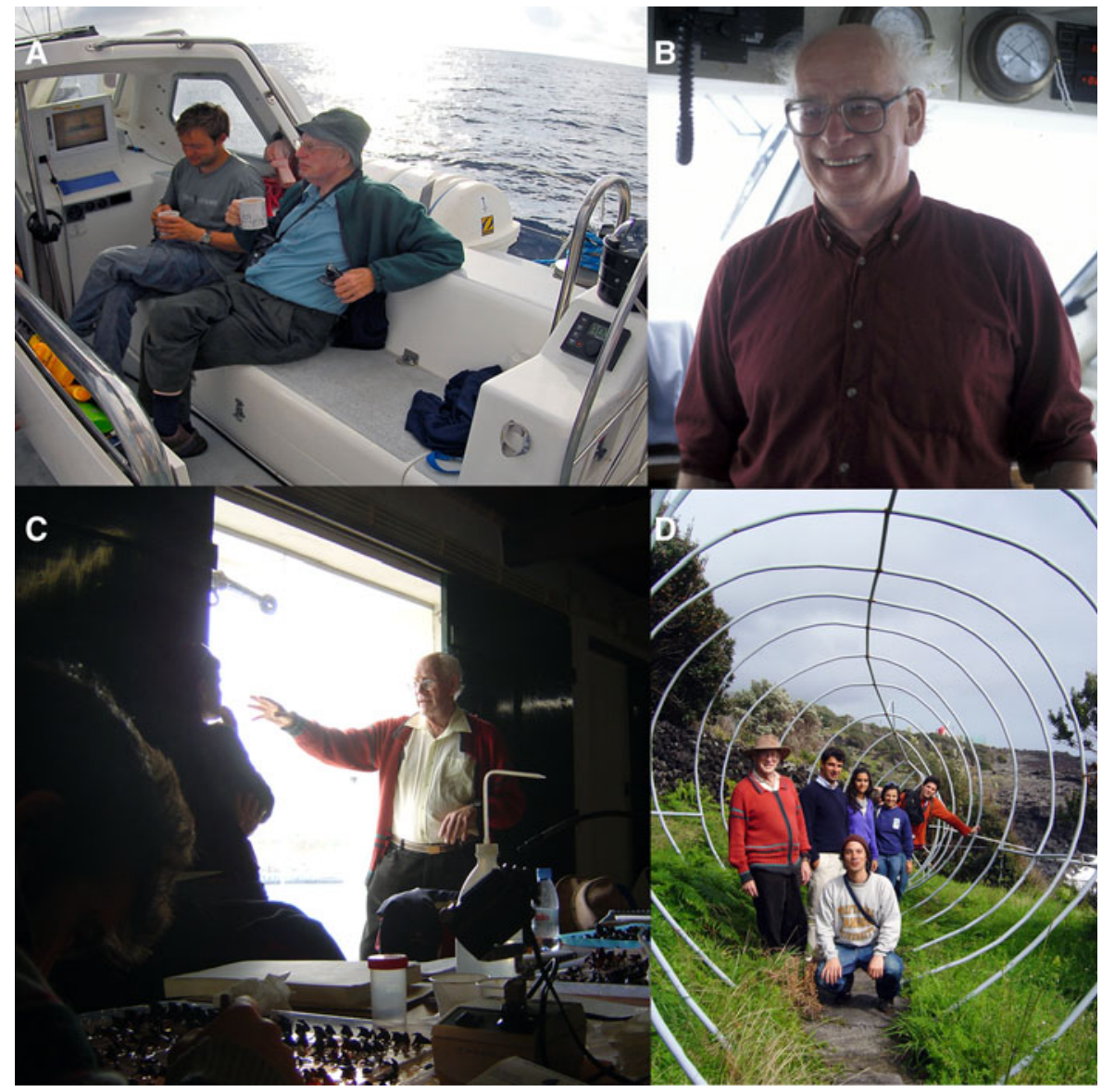

Fig. 2. Malcolm Clarke in the Azores: (top left) during a cetacean survey off Pico Island aboard RV 'Song of the Whale' in collaboration with IFAW (20o8; source: J. Quaresma); (top right) at the bridge of RV 'Arquipelago' (source: H.R. Martins); (bottom left) lecturing an international workshop about cephalopod beaks on Faial Island (2007; source C. Pham); (bottom right) inside the life size sperm-whale model at his museum on Pico Island, with José Xavier on his left side and some of the attendees of the cephalopod identification workshop (front to back, C. Pham, J. Barcelos, M. Freitas and Paulo Soares in 2007).

squid. In 1997, alongside Clyde F.E. Roper (Smithsonian National Museum of Natural History), they sailed to the Azores and later to New Zealand. In 2012 a film crew lead by Martin Dorhn attempted to film Architeuthis dux in the Azores, consulting Malcolm for advice. Such documentaries had worldwide broadcast, revealing the Azores marine life, in particular the deep-diving whales and giant squid.

\section{Talks}

At a regional level, he was also very active. Malcolm was a regular presence in Semana das Pescas. He was also deeply involved in Bienal das Baleias (Biannual Conference on Cetaceans) on Pico Island 1999-2004.

\section{Museum of the Sperm Whales and Squids 'dos Cachalotes e Lulas'}

Malcolm's most important contribution to scientific dissemination in the region, is perhaps the Museum of the Sperm Whales and Squids that he created with his wife Dot. The museum was entirely self-funded and was built by Malcolm and Dot in their home estate, opening to the public in 2003. It comprises 28 sections (Figures 3 and 4): (1) sperm whales are mammals; (2) vertical section of the largest female sperm whale ever measured in the Azores; (3) bones and skeleton: shapes, densities, proportions; (4) lungs and air; breath holding; (5) diving; (6) dealing with light, temperature, pressure and density; (7) swimming; (8) history of the skin; (9) ambergis; (10) light; (11) eyes; (12) use of sound; (13) hearing; (14) intelligence and emotions; (15) the brain; (16) growth, size and shape, age; (17) behaviour; (18) distribution and migration; (19) food; squids; colossal and giant squids; (20) squids and octopuses: deep sea cephalopod colour, lights, swimming, lives; (21) return to the sea; (22) comparisons of the whales; (23) parasites; (24) enemies, humans; (25) commercial killing, stranding, population; (26) the pigmy sperm whale, Kogia: skeleton, the nose; (27) cetacean evolution: Basilosauros, Dorudon; and (28) how big was the largest sperm whale caught in the Azores? Walk through!

Malcolm cooperated with several museums during his life: the Natural History Museum of London (UK); the Smithsonian National Museum of Natural History, Washington, DC and Los Angeles Natural History Museum (USA); Melbourne Museum (Australia); Museum of New Zealand Te Papa Tongarewa (N.Z.); National Museum of Natural Science (Taiwan); National Museum of Nature and Science (Japan); and South African Museum, Cape Town and Port Elizabeth Museum (South Africa). In his own words, Malcolm 'examined the methods of exhibition in those as well as in Berlin, Paris and Santa Barbara (USA) 

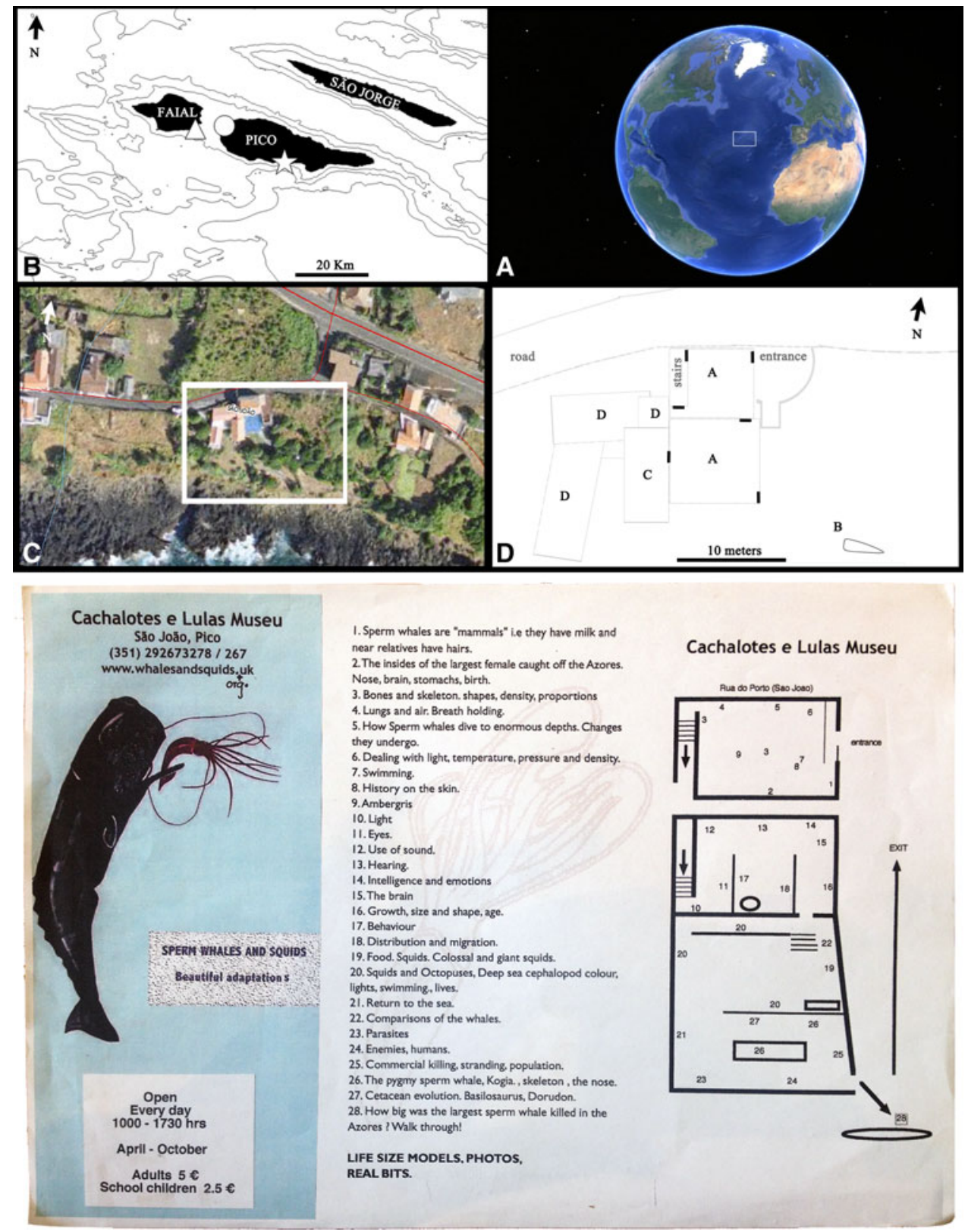

Fig. 3. Museum of the Sperm Whales and Squids: (A) North Atlantic context; (B, C) location in Pico Island (star symbol), location of the new museum facilities (circle symbol) and the University facilities on Faial Island (triangle symbol); (D) museum floor plan including display rooms (A), exterior life-size whale (B), laboratory (C) and house (D); below the museum flyer with indication of price and exhibition content; see text for more information (sources: images (A, C) Google Earth (C); image(B) $500 \mathrm{~m}$ depth contour lines plotted in ArcGIS using Gebco $30^{\prime}$ ).

Museums', which served as the basis to create the concept of a totally new exhibit about the biology of spermaceti whales (Physeter macrocephalus, Kogia simus and K. breviceps) and their cephalopod prey.

The exhibit concept created by Malcolm for the Museum of the Sperm Whales and Squids is completely innovative, in great part due to the careful planning but also due to creative solutions to cope with the budgetary constraints. The exhibit used low technology and everyday use objects to convey the information on the subject in a simple, accessible but accurate manner, in the same style of Malcolm's presentations (Figure 4).

In 2012 the exhibit was acquired by the Municipality of Vila da Madalena, in Pico Island (Figure 4), opened to the public 22 of June 2014, in a new facility in Madalena do Pico, with the coordination of the Azorean Marine Observatory (OMA) and the Regional Secretary for Education, Science and Culture. The overall content about sperm whales and their prey was maintained and adapted to the new panels, including the real-size sperm whale section and the cephalopod models developed by Dot. It is a unique asset for the region, being the only museum of its kind in the world and carrying the name of one of the lead scientists in his field.

\section{FINAL REMARKS}

This paper is meant to serve as a tribute to the work and life of Malcolm Clarke. All authors were influenced by him both 


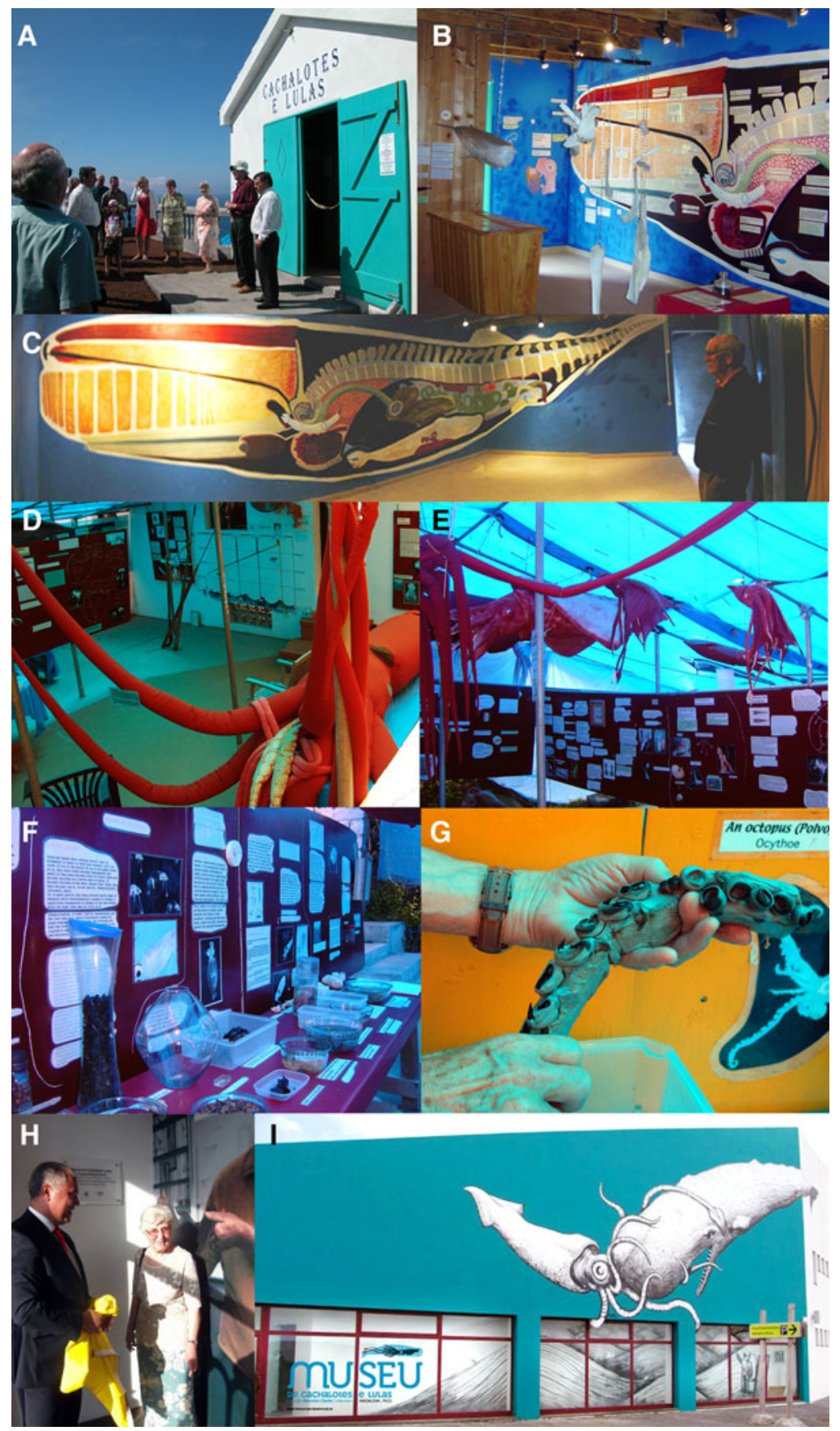

Fig. 4. (A) Malcolm and Dot receiving visitors at the entrance of the Museum of the Sperm Whales and Squids (2004); (B) entrance view; (C) Malcolm looking at the fresh wall paint of a life size sperm whale in the first room; (D) Architeuthis dux model and hunting harpoons in the back; (E) view of exhibition panels section 20 and cephalopod models hanging (Taningia danae and histioteuthids); (F) display of cephalopod information including upper and lower beaks (another panel from section 20); (G) Malcolm showing the arm and hooked suckers of a Mesonychoteuthis sp.; (H) Dorothy Clarke and the local Mayor José Soares at the re-opening of the museum in Madalena do Pico, 22 June 2014; (I) exterior facade of the new museum (artwork by Luis Brum).

professionally and personally. Hopefully this paper shows that his presence in the Azores had a positive and at least partially measurable influence on the regional marine science. Science and technical expertise are important factors for economic growth, making the scientific output an important measure of the nation's economic condition and social development (King, 2004; Jaffe et al., 2013). Through his constant cooperation with regional researchers, Malcolm contributed directly to improve the scientific output of the Region. Since he had ongoing work with several researchers in the Region, it is expected that new publications that include his name will soon appear.
The scientific role of Malcolm Clarke in the Azores is much more than his published papers, including promoting the growth of a newly created research centre, teaching generations of researchers, and outreaching science to a wider audience-culminating in the creation of a museumperpetuating his life occupation of revealing the unknown about giant whales and squids.

Through the creation of such unique museum, Malcolm and Dot contributed both to the tourism industry and to the cultural aura around whales and their prey, forever associated with the Azorean people from their recent whaling history. By 
passing it to the hands of the local population, he created an opportunity for future generations to benefit both culturally and economically from his presence in the Azores. It is in our hands to guarantee that this opportunity is seized and his memory is kept alive.

\section{ACKNDWLEDGEMENTS}

This manuscript was presented at the symposium in honour of Malcolm Clarke 'The role of cephalopods in the world's oceans', organized by Elizabeth K. Shea, Jose Xavier and Marek Lipinski (sponsored by Cephalopod International Advisory Council-CIAC) during the World Congress of Malacology, 21-27 June 2013, PDL Azores. The authors wish to acknowledge the three referees who commented on the first version of the manuscript, and all friends who kindly contributed with photographs.

\section{FINANCIAL SUPPDRT}

J.N.G.P. was supported by a doctoral grant from the Regional Directorate for Education, Science and Culture, of the Regional Government of the Azores (M3.1.2/F/o62/2011). LARSyS-Associated Laboratory no. 9 funded by the Portuguese Foundation for Science and Technology (FCT) through pluriannual and programmatic funding schemes (OE, FEDER, POCI2001, FSE) and by the Azores Directorate for Science and Technology (DRCT).

\section{REFERENCES}

Brierley A.S., Thorpe J.P., Clarke M.R. and Martins H.R. (1993) A preliminary biochemical genetic investigation of the population structure of Loligo forbesi Steenstrup, 1856 from the British Isles and the Azores. In Okutani T., O'Dor K. and Kubodera T. (eds) Recent advances in cephalopod fisheries biology. Shimizu City: Tokai University Press pp. 59-67.

Brierley A.S., Thorpe J.P., Pierce G., Clarke M. and Boyle P. (1995) Genetic variation in the neritic squid Loligo forbesi (Myopsida: Loliginidae) in the northeast Atlantic Ocean. Marine Biology 122, $79-86$.

Clarke M.R. (1962a) Significance of cephalopod beaks. Nature 193, 560561.

Clarke M.R. (1962b) The identification of cephalopod 'beaks' and the relationship between beak size and total body weight. Bulletin of the British Museum (Natural History) Zoology 8, 419-480.

Clarke M.R. (1966) A review of the systematics and ecology of oceanic squids. Advances in Marine Biology 4, 91-300.

Clarke M.R. (1983) Instructions for the collection and preservation of cephalopod beaks. In BIOMASS Report Series, Volume 33, pp. 23-81.

Clarke M.R. (1986) A handbook for the identification of cephalopods beaks. Oxford: Clarendon Press.

Clarke M.R. (1996) The role of cephalopods in the world's oceans: general conclusion and the future. Philosophical Transactions of the Royal Society of London. Series B: Biological Sciences 351, 1105-1112.

Clarke M.R. (2006) Oceanic cephalopod distribution and species diversity in the eastern north Atlantic. Arquipelago-Life and Marine Sciences $23,27-46$.
Clarke M.R. (2007) Seamounts and cephalopods. In T.J. Pitcher, T. Morato, P.J. Hart, M.R. Clark, N. Haggan and R.S. Santos (eds) Seamounts: ecology, fisheries and conservation. Chichester: John Wiley \& Sons, pp. 207-229.

Clarke M.R., Clarke D.C., Martins H.R. and Da Silva H.M. (1996) The diet of the blue shark (Prionace glauca L.) in Azorean waters. Arquipelago Bulletin of the University of the Azores-Life and Earth Sciences 14, 41-56.

Clarke M.R., Clarke D.C., Martins H.R. and Silva H.M. (1995) The diet of swordfish (Xiphias gladius) in Azorean waters. Archipelago-Life Marine Sciences A 13, 53-69.

Clarke M.R. and Martins H.R. (1994) Marine Azorean Foodwebs-the known, the unknown and the unlikely. In Proceedings of $13^{a}$ Semana das Pescas. Horta: Secretaria Regional da Agricultura e Pescas, pp. 73-8o.

Clarke M.R., Martins H.R. and Pascoe P. (1993) The diet of sperm whales (Physeter macrocephalus Linnaeus 1758) off the Azores. Philosophical Transactions of the Royal Society of London. Series B: Biological Sciences 339, 67-82.

Clarke M.R. and Merrett N. (1972) The significance of squid, whale and other remains from the stomachs of bottom-living deep-sea fish. Journal of the Marine Biological Association of the United Kingdom 52, 599-603.

Clarke M.R. and Pascoe P. (1997) Cephalopod species in the diet of a sperm whale (Physeter catodon) stranded at Penzance, Cornwall. Journal of the Marine Biological Association of the United Kingdom 77, $1255-1258$.

Den Hartog J. and Clarke M. (1996) A study of stomach contents of Cory's Shearwater, Calonectris diomedea borealis (Cory, 1881) (Aves: Procellariidae), from the Macaronesian Islands. Zoologische Mededeelingen 70, 117-133.

Guénnette S. and Morato T. (2001) The Azores Archipelago, 1997. Fisheries Centre Research Reports 9, 241-270.

Hatfield F. and Hochbergand E. (2002) A brief history of the cephalopod international advisory council (CIAC). Bulletin of Marine Science 71, $17-30$.

Jaffe K., Caicedo M., Manzanares M., Gil M., Rios A., Florez A. and Davila V. (2013) Productivity in physical and chemical science predicts the future economic growth of developing countries better than other popular indices. PloS One, 8, e66239. doi:10.1371/journal.pone. 0066239

King D.A. (2004) The scientific impact of nations. Nature 430, 311-316.

Lemey E. (2013) Towards ecosystem based management of the Azores marine resources: developing an ecosystem model and fitting to time series data of abundance and catch. MSc thesis in Marine Biodiversity and Conservation. Ghent University, Belgium, 71 pp.

Martins H.R., Clarke M.C., Reiner F. and Santos R.S. (1985) A pygmy sperm whale, Kogia breviceps (Blainville, 1838) (Cetacea: Odontoceti) stranded on Faial Island, Azores, with notes on cephalopod beaks in stomach. Arquipelago: Série Ciências da Natureza 6, 63-70.

Morato T., Santos R.S. and Andrade J.P. (2000) Feeding habits, seasonal and ontogenetic diet shift of blacktail comber, Serranus atricauda (Pisces: Serranidae), from the Azores, north-eastern Atlantic. Fisheries Research 49, 51-59.

Morato T., Sola E., Grós M. and Menezes G. (2003) Diets of thornback ray (Raja clavata) and tope shark (Galeorhinus galeus) in the bottom longline fishery of the Azores, northeastern Atlantic. Fishery Bulletin $101,590-602$.

Nesis K. (1993) Cephalopods of seamounts and submarine ridges. In O'Dor O.T.R.K. and Kubodera T. (eds) Recent advances in cephalopod fisheries biology. Tokyo: Tokay University Press, pp. 365-373. 
Neves V., Nolf D. and Clarke M.R. (2012a) Spatio-temporal variation in the diet of Cory's shearwater Calonectris diomedea in the Azores archipelago, north-east Atlantic. Deep-Sea Research Part I: Oceanographic Research Papers 70, 1-13.

Neves V.C., Bried J., González-Solís J., Roscales J.L. and Clarke M.R. (2012b) Feeding ecology and movements of the Barolo shearwater Puffinus baroli baroli in the Azores, NE Atlantic. Marine Ecology Progress Series 452, 269-285.

Neves V.C., Nolf D. and Clarke M. (2011) Diet of Bulwer's Petrel (Bulweria bulwerii) in the Azores, NE Atlantic. Waterbirds 34 357-362.

Pereira J.N., Morato T., Menezes G., Clarke M.R. and Barcelos L. (2010) Cephalopods in the diet of two seamount aggregating fish species: alfonsino, Beryx splendens and orange roughy, Hoplostethus mediterraneus. Poster presented in Project HERMIONE - 2nd Annual Science Meeting, Málaga, Spain.

Pitcher T.J., Morato T., Hart P.J., Clark M.R., Haggan N. and Santos R.S. (2007) Seamounts: ecology, fisheries and conservation. Oxford: Blackwell Publishing.
Rodhouse P.G., Lu C.-C. and Roper C.F. (2014) Malcolm Roy Clarke, FRS. Journal of the Marine Biological Association of the United Kingdom, 1-6.

Vidal E.A., Vecchione M. and von Boletzky S. (2014) Dedication to Professor Malcolm R. Clarke (1930-2013). Hydrobiologia 725, 1-1.

and

Xavier J., Clarke M.R., Magalhães M.C., Stowasser G., Blanco C. and Cherel Y. (2007) Current status of using beaks to identify cephalopods. In III International Workshop and training course on Cephalopod beaks, Faial island, Azores, April 2007.

\section{Correspondence should be addressed to:}

J.N. Gomes-Pereira

IMAR and Department of Oceanography and Fisheries University of the Azores 9900 Horta, Faial, Portugal email: josenunopereira@uac.pt 